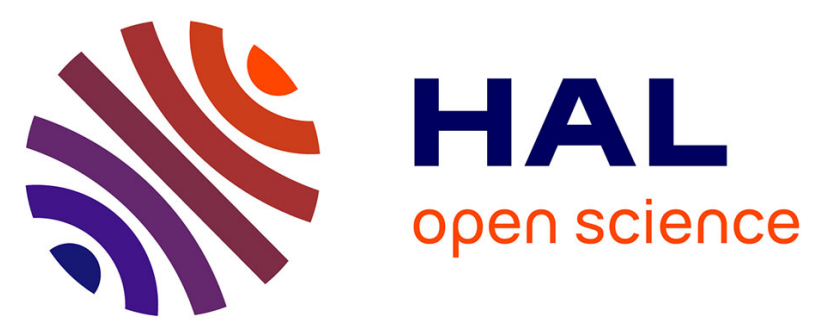

\title{
ESCAPADE: Coordinated multipoint measurements of Mars' unique hybrid magnetosphere
}

Robert Lillis, Shannon Curry, Janet Luhmann, Yingjuan Ma, Aroh Barjatya, Phyllis L Whittlesey, Roberto Livi, Davin Larson, Shaosui Xu, Christopher Russell, et al.

\section{To cite this version:}

Robert Lillis, Shannon Curry, Janet Luhmann, Yingjuan Ma, Aroh Barjatya, et al.. ESCAPADE: Coordinated multipoint measurements of Mars' unique hybrid magnetosphere. 14th Europlanet Science Congress 2020, Sep 2020, Online, Germany. pp.EPSC2020-511, 10.5194/epsc2020-511 . insu03112738

\section{HAL Id: insu-03112738 \\ https://hal-insu.archives-ouvertes.fr/insu-03112738}

Submitted on 17 Jan 2021

HAL is a multi-disciplinary open access archive for the deposit and dissemination of scientific research documents, whether they are published or not. The documents may come from teaching and research institutions in France or abroad, or from public or private research centers.
L'archive ouverte pluridisciplinaire HAL, est destinée au dépôt et à la diffusion de documents scientifiques de niveau recherche, publiés ou non, émanant des établissements d'enseignement et de recherche français ou étrangers, des laboratoires publics ou privés. 


\section{ESCAPADE: Coordinated multipoint measurements of Mars' unique hybrid magnetosphere}

\section{Robert Lillis et al. '}

Multi-spacecraft missions after 2000 (Cluster II, THEMIS, Van Allen Probes, and MMS) have revolutionized our understanding of the causes, patterns and variability of a wide array of plasma phenomena in the terrestrial magnetospheric environment. ESCAPADE is a twin-spacecraft Mars mission concept that will similarly revolutionize our understanding of how solar wind momentum and energy flows throughout Mars' magnetosphere to drive ion and sputtering escape, two processes which have helped shape Mars' climate evolution over solar system history.

ESCAPADE will measure magnetic field strength and topology, ion plasma distributions (separated into light and heavy masses), as well as suprathermal electron flows and thermal electron and ion densities, from coordinated elliptical, $200 \mathrm{~km} \times \sim 7000 \mathrm{~km}$ orbits. ESCAPADE are small spacecraft $(<150 \mathrm{~kg})$, traveling to Mars via solar electric propulsion as a rideshare with the Psyche metal-asteroid mission in August 2022. ESCAPADE's strategically-designed 1-year, 2-part scientific campaign of temporally and spatially-separated multipoint measurements within and between the different regions of Mars' diverse plasma environment, will allow the cause-and-effect of solar wind control of ion and sputtering escape to be unraveled for the first time. Figure 1 shows ESCAPADE's orbits within a hybrid simulation of the solar wind interaction with Mars, where the color scale represents ion velocity, blue lines are magnetic field, while white lines are sample proton trajectories and spacecraft orbits.

ESCAPADE is due to complete its preliminary design review in August 2020, thereafter moving toward build, test, integration and launch two years later. We will report on science goals and objectives, mission design challenges, and provide a status update.

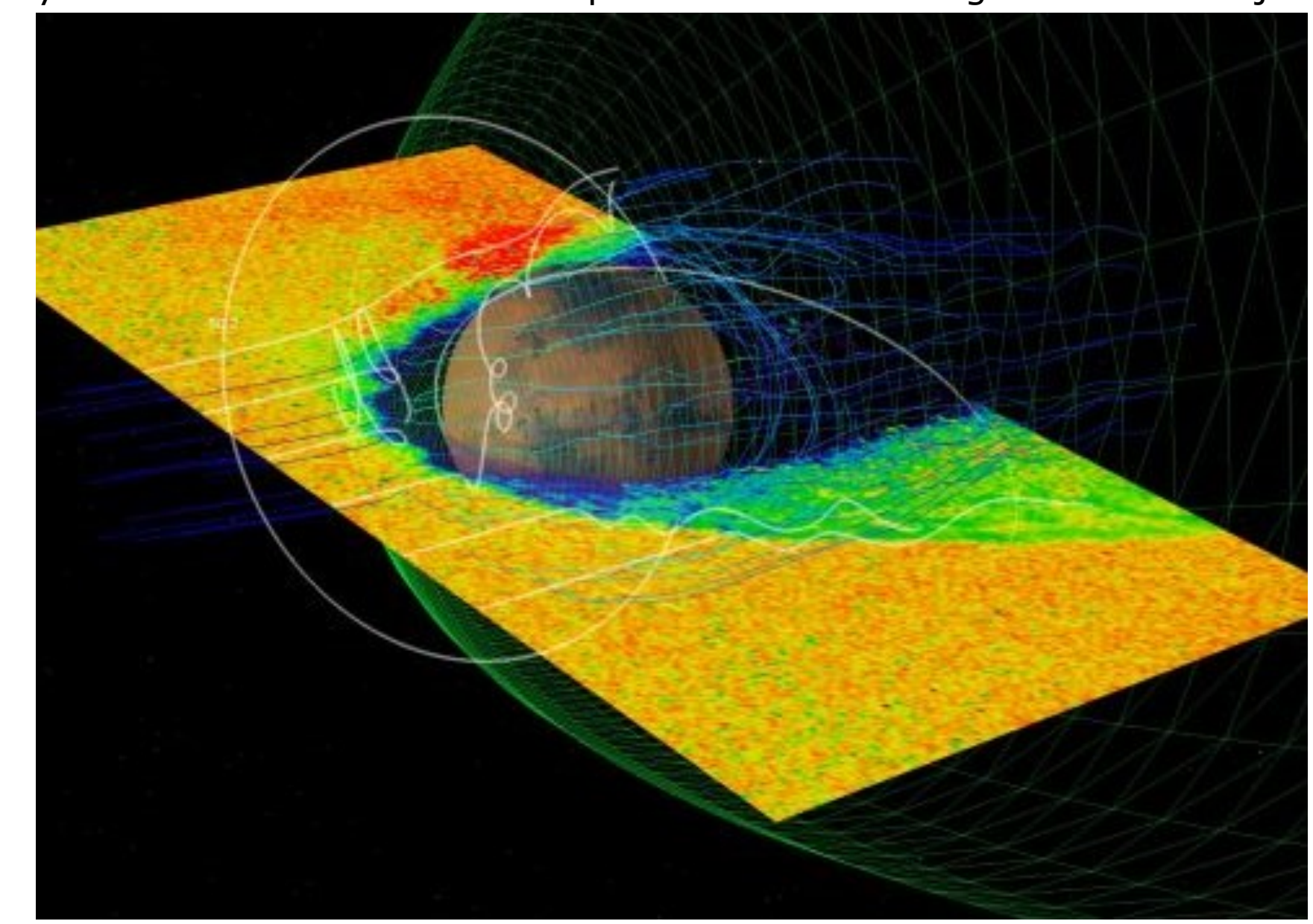

How to cite: Lillis, R., Curry, S., Luhmann, J., Ma, Y., Barjatya, A., Whittlesey, P., Livi, R., Larson, D., Xu, S., Russell, C., Fowler, C., Brain, D., Thiemann, E., Withers, P., Modolo, R., Harada, Y., and Berthomier, M.: ESCAPADE: Coordinated multipoint measurements of Mars' unique hybrid magnetosphere, Europlanet Science Congress 2020, online, 21 September-9 Oct 2020, EPSC2020-511, https://doi.org/10.5194/epsc2020-511, 2020 


\section{Contact}

Imprint

Contact

Data protection 